\title{
Analysis of Organic Pangasius Value Chain in the Mekong Delta, Vietnam
}

\author{
Le Nguyen Doan Khoi
}

\begin{abstract}
Organic products remain a niche market in most countries and there is relatively little international trade in organic aquaculture products (Smith et al., 2005). The newly emergent organic products tend to exclude small-holders due to reasons of high certification costs, smaller volumes they produce, and tighter control of product quality. The paper looks at some of the opportunities that exist for small-holders to enter organic schemes and compete in the niche markets. Importantly, the constraints and risks that are involved will be debated. The ability of small farmers to organize and obtain the certification is questioned and the mechanisms to facilitate this will be discussed. The value chain concept, quality management, the theory of institutions and transaction cost economics, will be applied to analyze how the coordinated efforts of various stakeholders can be developed to achieve a better product quality and quality assurance.
\end{abstract}

Index Terms-Organic Pangasius, Quality Assurance, Governance, Small-Holders, Value Chains

\section{INTRODUCTION}

The organization of food supply chain has changed toward closer vertical integration between the stages in the chain (Boger, 2001; Hobbs, 2000). Fish production systems are characterized by the production of raw materials coming from fish culture, processing, followed by distribution and retail and finally consumer processing. Production systems have the creation of quality in common, but also the maintenance of quality throughout the entire food supply chain in order to provide consumers with high quality products. One of the critical choices that firms make concerns determining the degree of vertical integration; e.g. deciding which activities should be performed in-house and which activities should be carried out in co-operation with suppliers or customers. As Pangasius industry concern, the vertical integration systems between fish farmers and processing/export firms have dramatically shifted toward long- term contract coordination. It has been indicated that consumers demand for food quality and safety has been a pivotal factor in increasing vertical integration in the food industry.

Theories of industrial organization and inter-firm relations provide a useful basis for understanding the nature of vertical integration and its effect on firm's performance. Scholars of industrial organization view vertical integration as a strategic tool in creating competitive advantage (Porter, 1985; Barney, 1991). From the perspective of transaction cost economics (TCE), vertical integration is viewed as one form of governance structure that is determined by attributes

Published on June 26, 2019

Le N. D. Khoi is with Can Tho University, Vietnam. of transaction and assumptions of human behavior (Williamson, 1985). The basic question to be analyzed TCE is what kind of governance structure provides an efficient framework for transactions with varying level of asset specificity (Borger, 2001). Governance is required when the supplier lacks technical competence or market knowledge. Some firms may vertically integrate their activities with the objective of minimizing transaction costs, increasing their control over resources, capturing more rent, increasing entry barriers and foreclosing competitors. Vertical integration has considerable benefits, but also implies significant risks and costs. However, vertical integration requires a high capital investment, and it may result in reduced flexibility and increased bureaucratic costs.

\section{RESEARCH BACKGROUND}

Aqua-cultured fish is one of the dominant export products in Vietnam. The development of this sector is a major source of foreign currency and employment opportunity. The success of the sector encourages both local and foreign investment. Vietnam has a coastline of more than $3,200 \mathrm{~km}$ long with over 3,000 islands, a wealth of natural inland water bodies (lakes and rivers) and area of ponds and seasonal flooded grounds. The total water area is still increasing by the construction of new dams and reservoirs.

Although the economic conditions for the Pangasius look promising, there are problems in the Vietnamese Pangasius industry. Europe and America have and are erecting stricter quality standards for fish products. The major processing factories in Vietnam are complying with those quality demands. However, at the moment most smallholders cannot comply with the standards that the processing factories required (Macfadyen, 2004, Schutz, 2006). To ensure a stable income for the smallholders, the current and future quality demands need to be met. The problem situation is viewed from a value chain perspective, in which the quality system is managed through a distinction of technological and managerial functions. With this perspective the conventional and organic chain are analyzed regarding their quality system and the most important chain performance drivers.

\section{LITERATURE REVIEW}

\section{A. Value chain and quality management:}

The concept of value chain is relevant to firms involved in food businesses. According to Porter (1985), the value chain describes the full range of activities which are required to bring a product or service from conception, 
through the different phases of production (involving a combination of physical transformation and the input of various producer services), delivery to final consumers, and final disposal after use. There are three key elements of value chain analysis - barrier to entry and rent, governance, and systemic efficiency (Kaplinsky, 2000). In agribusiness, the value chains are organized linkages among groups of producers, traders, processors and service providers who joint together in order to improve quality and the value added of their activities (Johnson, 2005).

\section{B. Quality management}

The quality performance of the end product is determined throughout the total value chain, and starts at the beginning of the chain. If the farmer starts with weak fingerlings that are receptive to disease and treats them with forbidden antibiotics, this can have consequences for the whole supply chain. The same goes for the process temperature; if this is too high, the amount of bacteria can multiply too fast. Thus, quality needs to be managed. Luning et al., (2007) proposed a techno-managerial approach for food quality management as a way to analyze and solve the complex quality issues. They do not define the primary and secondary activities of Porter (1995), but define different technology dependant and decision-making activities. Both the use of technology to understand behaviour of living fish and the use of managerial sciences to understand human behaviour of chain actors are needed.

\section{1) Technical functions}

The technological functions are described as technology dependant activities necessary to achieve a product with certain physical properties. These are tools, equipment or methods used to produce goods and production and measuring activities to provide information about the status of the product. Luning and Marcelis (2007) state that you can distinguish three technological functions that are very comparable with Porter's (1995) first three primary activities of Porter (1995), namely:

- Physical supply and storage of incoming food materials (inbound activities).

- Transformation of food materials into processed food products (transformation).

- Physical storage and distribution of processed food products (outbound activities).

These technical functions have consequences for both the intrinsic and extrinsic quality attributes for the product. A bad freezer or a dirty cutting knife will have consequences for health issues, as dirty farming water has for the colour of the meat. With a conventional farm it is impossible to comply with the extrinsic quality demands of organic farming.

\section{2) Managerial functions}

Managerial functions are defined as the necessary decision-making activities to activate the food production system as well as the management system. The fish value chain is complex and there are many stakeholders involved in production operations. Therefore, human behaviours play a crucial role due to unpredictable and changeable handling. As a consequence, the result of fish industry, as the combined action of individuals working with agro-food products and striving for quality, is much more uncertain than often is assumed (Luning et al., 2007).

3) Decision making for product quality

The product quality in the technical function is dependent on the product or food dynamics on the one hand, such as variability in properties due to variable compositions, enzyme activities and on the other hand the technological conditions like the process, equipment and building circumstances (Luning et al., 2007).

The human behavior within the management system is on one side dependent on human dynamics like variability in decisions due to e.g. different perceptions, attitudes and on the other side determined by administrative conditions procedures. The managerial functions design, control, improvement, assurance, and policy and strategy have been distinguished from the technical functions. However, all managerial functions are decision-making activities that influence and activate the food production system. That is why Luning and Marcelis (2007) characterize decisions on food/human dynamics and technological/administrative conditioning, for each managerial function.

When the situation of the smallholders and the quality management is analyzed, these functions and decisions can offer structure for the criteria that have to be met. For a decision on a technical condition (i.e. process requirement) there has to be a quality control and assurance measure to guarantee the quality policy and strategy.

\section{RESEARCH METHODS}

The case study is used for designing this research. The research approach is problem solving in nature. The reason for selecting this approach is that because our research is mainly aimed at coming up with problems related to quality management of organic fish by investigating the supply linkages between the fish stakeholders.

The research initially started as a desk research to investigate the quality demands set by the EU and labels. Reports and internet sites were used to gather information about the demands and the status of labels. In some cases, extra information was obtained through telephonic interviews or email correspondence with the labels or authorities. The first goal was to find out what the minimal EU standard was. The second goal, to inquire how suitable a strategy of each label is for the smallholders, and what their current status is regarding aquaculture in Vietnam. This resulted in the EU and the Naturland demands. Then, we carefully selected our cases from different chain stakeholders (fishery experts, the hatcheries, farm input suppliers, small farmers, traders, and processors/exporters). Most of the interviews were conducted semi-structured with predefined open questions to make sure all topics were covered, meanwhile allowing enough space to elaborate on important issues. Each interview lasted between 60 to 120 minutes.

\section{Case Study Results}

\section{A. Current organic value chain}

The organic Pangasius value chain is differently 
organized than the regular one. Binca, the exporter to Europe, fulfils a strong coordinative function. Binca has a big influence on the procedures on the farm. This is why Binca and farm will be discussed together. After this the processor, the distributor and the role of the third party quality assurance are discussed. Now the current status of the organic project is discussed.

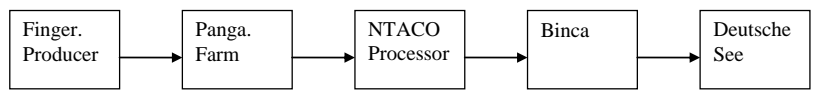

Fig. 1. Overview of the organic Pangasius value chain

\section{B. The status of the organic Pangasius project}

Binca Seafood, Naturland and GTZ work together in Vietnam to produce organic Pangasius in the An Giang province. Binca Seafood is a relatively small company and imports primarily deep-frozen seafood from Asia to Europe. According to them the organic aquaculture is a growing high-end niche market. The increase of organic food can be seen all over the world. GTZ is an international cooperation enterprise for sustainable development. They promote reforms and change processes. Its corporate objective is to improve people's living conditions on a sustainable basis. (http://www.gtz.de/en/unternehmen/689.htm)

The two farmers with which Binca cooperates are both members of AFA. In cooperation with AFA they were chosen as most suitable for the organic culture, location was a key factor. The most important aspects of the location are the fact that there is no industry nearby and that the erosion caused by the river is minimal. Erosion forms a problem when pens are used. The river erodes which causes wholes underneath the fence through which fishes escape.

The work on certification and $3^{\text {rd }}$ party quality assurance is carried out by IMO, with a department in Hanoi, strongly reducing certification costs and building up the regional know-how on organic certification. The Naturland and BioSuisse label give respectively excess to the German and Swiss organic market.

The project is still in its development phase. An example of this is the organic feed supply. Earlier homemade feed was used. The feed consisted out of $50 \%$ rice bran, $25 \%$ soybean, $25 \%$ fish meal. The soybean oil was imported from the Dalian Xinlongken factory in China in loose container loads. For all the supplies certificates from OCIA International were available stating the organic quality. The containers are unloaded in My Thoi Harbour and repacked. The bagging activities were monitored by the Binca representative. After this the bags were transported to the farm by boat.

The rice has to be sourced from organic farming. But this could not be met at that stage of the project. Therefore, the rice bran was bought from traditional farming. Each lot of rice supplied to the farm was subject to analysis to verify that the rice was free from residues. This was done by Can Tho University at the Advanced Laboratory for pesticides and chemicals. The problem with the fish meal was that there was no organic certificate for this product. Each time analyses were done to control the quality. It should be clear that the process for certification of this type of feed is very complex which increases the costs and reliability. At the moment (2007), organic industrial Pangasius feed is produced by a qualified organic producer from Israel (Raanan) and imported by Binca.

GTZ claims that the farmers earn more than $15 \%$ more then on the conventional market (http://www.smegtz.org.vn). In 2006 Binca produced around 1000 tons of organic Pangasius which is approximately 330 tons of fillets.

\section{1) Binca Seafoods}

Binca is one of the initiators for the farming of organic Pangasius in Vietnam, the first country where Pangasius is farmed organically. Besides the function of exporter Binca governs the organic supply chain in Vietnam, they check the farming and the processing of the Pangasius. They invested in the intrinsic and tacit knowledge of how to apply for the organic standards and how to govern the quality control for the assurance of the organic product. As A. Bui says during the interview: "One of our business advantages is that we know how to get through the whole certification process".

The information in this chapter has been obtained by semi-structured interviews with the Binca manager in Vietnam (A. Bui) and a university trainee (G. Poitevin) combined with a visit to the farm of Mrs. Dung, one of the two farms contracted by Binca.

\section{2) Organic Pangasius farm}

There are no conventional aquaculture activities in the neighbourhood and there is no risk of conventional fish entering the organic enclosures. Apart from this there is separate housing for the farmers, a fish food barn and a toilet as stated in the official regulations for organic farming. There are also watchtowers for security reasons.

The pond and enclosures are located near to each other to facilitate a short fish transport. Binca has a second farm at which the pond and pens are more scattered. This makes it harder to transport the fish and to do all the quality checks in one day.

\section{3) Farming activities}

The fingerlings are bought at a normal hatchery, private or state owned. There is a higher integration in this part of the chain because no fingerling traders are used. Three weeks before they are bought a test is done to check for traces of antibiotics. This test has to be documented. When the fingerlings are purchased another document has to be distributed with the weight of fingerlings bought. These two documents are the first step in the traceability of the product. After this a sample of fingerlings is taken to calculate the average weight. Because the purchased weight is known an estimation of the amount of fingerlings can be made. This is the input for the farming process.

\section{4) NTACO}

NTACO is a certified fillet processor by Naturland and Bio-Suiss. The factory controls the product quality according the standard of GMP-SSOP-HACCP plan and ISO 9002. Binca rents the facilitation of the processor for 2 days to process their fish. In this construction employees of Binca are present when the fish are processed. In this way they can assure that the organic fish stay separated from the non-organic fish. The differences in the production are mainly that the transportation and slaughtering time are ensured and the fish are made unconscious by dipping them 
in water of 7 degrees for 2 minutes. All the waste water is purified before being released into the Mekong River. The water purification is not unique for NTACO but is also done by other modern processors. So apart from the stunning the fish there are no major differences in the process normal process in the factory. The fish are processed and labeled to ensure the traceability of the product.

Binca could create extra added value of the trash products. One could think about organic fish sauce of organic galantine.

\section{5) DeutscheSee}

DeutscheSee is a fish manufacturer that sells a wide range of value added products, including: the whole fish, organic Pangasius fillet, organic Pangasius fillet with curry or garlic and now ever organic Pangasius fish sticks. With the last product DeutscheSee not only focuses on the healthy image of fish but also on the fast food fish market. As mentioned before they have a contract with Binca that enables them to have the 'monopoly' of Binca's organic Pangasius on the German market.

\section{6) External quality assurance}

The Institute for Marketecology (IMO) is a specialist in quality assurance of eco-friendly products, organic agriculture and management systems (http://www.imo.ch). IMO is the third party that checks if the production of Binca can be assured as organic regarding the standards Naturland and Bio-Suiss. IMO hires consultant Philippe Serene, who is accredited, to perform both the inspection as the checks.

Bioswiss demanded a $100 \%$ check on the production. This has as a consequence that IMO has to check all the harvests. The harvest at the farm, the processing at the factory and the documentation are inspected (i.e. whether the fish density and the fish transporting time is within regulation). All the documents are supplied by Binca.

\section{CONCLUSION AND RECOMMENDATIONS FOR BETTER GOVERNANCE}

The organic value chain in Vietnam is very complex and the farmers are the weakest links in the chain driven by exporters and importers. It is more difficult to use smallholders in organic farming. One should not forget the strategy of Naturland, which is organic farming. This is why a price premium is added. Naturland has social aspects included in the label, but it is not a label that emphasizes to work with smallholders. A Fair-trade could offer extra compensation because they work with smallholders. The adoption to fair-trade will be much easier then to organic. There is however no label for aquaculture and one can ask the question is if the market is big enough. It will only be a solution for a small proportion of the smallholders. Still it could be an interesting field to explore.

The Pangasius industry is developing vastly due to huge investments. These investments are made by companies that produce on a large scale. This could push the smallholders out of the chain. But there is no idea how many smallholders there in Vietnam or how much capacity they have. By pushing them out of the market a lot of capacity could be lost. On the other hand, when there is sufficient demand the product quality in this group will still be ungoverned. No information can be found about the location, density and the production outputs of the smallholders. It would be very interesting to see a map of Vietnam with the density of Pangasius farming combined with the average size of the farms in combination with the deviation on the average.

More investigation should be made about how to organize and stimulate the smallholders to work together. This should be stimulated so farmers can establish horizontal integration within the chain to stimulate i.e. the flow of information and their position within the chain. This is mentioned by other reports as well (FAO, 2006, Schutz, 2006)

Another interesting fact offered by AFA was that many smallholders with a capacity below the 20 tons per year switched to the production of fingerlings. The question for a research could the best way for the smallholders to develop. Maybe the fingerling production is much more stable.

\section{REFERENCES}

Asche, F., Khatun, F., (2006). Aquaculture: Issues and Opportunities for Sustainable Production and Trade. Natural Resources, International Trade and Sustainable Development.

Bakker, K. (2007). Vietnamese Pangasius industry: Current practices, developments and implications for export to the European Union. Solid Aquaculture solutions.

Delgado, Christopher et al., (2003), Fish to 2020 - Supply and demand in changing global markets. International Food Policy Research Institute. Penang, Malaysia: WorldFish Center.

Golafshani, N., (2003), Understanding reliability and validity in qualitative research, the qualitative report, Vol 8, No. 4, 597-607.

Huss, H., H., Ababouch, L., Gram, L., (2004). Assessment and management of seafood safety and quality Assessment and management of seafood safety and quality, Food and Aquaculture Organization of the United Nations.

Kaplinsky, R., (2000), Globalization and Un-equalization: What can be learned from value chain analysis, Journal of development studies, Vol.37, No.2, 117-146

Khoi, L.N.D., (2007), Description of Pangasius value chain in Vietnam, CAS Discussion paper No 56, Centre for International Management and Development Antwerp

Khoi, L.N.D., (2007), Report of multi-case study of Pangasius small-scale farming practices, unpublished report

Luning, P. A., Marcelis, W. J., (2007), A conceptual model of food quality management functions based on a techno-managerial approach. Trends in food science \& technology 18: p159-166.

Ministry of Fisheries and The World Bank, (2005), Fisheries and Aquaculture Sector Study. Vietnam.

Ministry of Fisheries and The World Bank, (2006), Guidelines for Environmental Management of Aquaculture Investments in Vietnam, EASRD.

Noori, H., Radford, R. (1995), Production operations: total quality and responsiveness. London: MCGrawhill.

Ruben, R., Tilburg, A., Trienekens, J. And Boekel, M., (2007), Linking market integration, supply chain governance, quality and value added in tropical food chains, Tropical food chains. Governance regimes for quality management. Wageningen Academic publishers

Tung N.T., Thanh N.V., Phillips M., (2004), Policy Research Implications of Liberalization of Fish Trade for Developing Countries: A Case Study of Vietnam, Food and Agriculture Organization of the United Nations, Rome.

Verkerk, R., Linnermann, A., Boekel, M., (2007), Quality Analysis Critical Control Points in comsumer-oiented agro chains; an ecomomic organisation perspective. Tropical food chains. Governance regimes for quality management. Wageningen Academic publishers

Yin, R.K., (2003), Case study research: Design and methods, 3rd edition, Sage publications, Thousand Oaks, London, New Delhi 